\title{
Design and Optimizations of Aceclofenac Bioadhesive Extended Release Microspheres
}

\author{
G. Prasad ${ }^{1 *}$, K. Devika ${ }^{2}$, P. Varshith ${ }^{2}$, B. Shravani ${ }^{2}$, E. Pavithra ${ }^{2}$ and Ch. Swathi ${ }^{2}$ \\ ${ }^{1}$ M. Pharm., Ph. D, Associate Professor, Department of Pharmaceutics, Unity College of Pharmacy, Telangana, India. \\ ${ }^{2}$ B. Pharm, Unity College of Pharmacy, Telangana, India.
}

*Corresponding Author: G. Prasad M. Pharm., Ph. D, Associate Professor, Department of Pharmaceutics, Unity College of Pharmacy, Telangana, India.

Received date: October 27, 2021; Accepted date: November 02, 2021; Published date: November 13, 2021

Citation: G. Prasad, K. Devika, P. Varshith, B. Shravani, E. Pavithra and Ch. Swathi (2021) Design and Optimizations of Aceclofenac Bioadhesive Extended Release Microspheres Development; J. Pharmaceutics and Pharmacology Research 4(4) DOI: 10.31579/2693-7247/055

Copyright: (C) 2021, G. Prasad, This is an open access article distributed under the Creative Commons Attribution License, which permit unrestricted use, distribution, and reproduction in any medium, provided the original work is properly cited.

\begin{abstract}
The oral route for drug delivery is the most popular, desirable, and most preferred method for administrating therapeutically agents for systemic effects because it is a natural, convenient, and cost effective to manufacturing process. Oral route is the most commonly used route for drug administration. Although different route of administration are used for the delivery of drugs, oral route remain the preferred mode. Even for sustained release systems the oral route of administration has been investigated the most because of flexibility in designing dosage forms.

Present controlled release drug delivery systems are for a maximum of 12 hours clinical effectiveness. Such systems are primarily used for the drugs with short elimination half life.

Keywords: microspheres; zaltoprofen; aceclofenac
\end{abstract}

\section{Introduction}

For many decades, medication of an acute disease or a chronic disease has been accomplished by delivering drugs to the patients via various pharmaceutical dosage forms like tablets, capsules, pills, creams, ointments, liquids, aerosols, injectable and suppositories as carriers [1]. To achieve and then to maintain the concentration of drug administered within the therapeutically effective range needed for medication, it is often necessary to take this type of drug delivery systems several times in a day. This results in a fluctuated drug level and consequently undesirable toxicity and poor efficiency. This factor as well as other factors such as repetitive dosing and unpredictable absorption leads to the concept of controlled drug delivery systems [2,3]. The word new or novel in the relation to drug delivery system is a search for something out of necessity. An appropriately designed sustained or controlled release drug delivery system can be major advance toward solving the problem associated with the existing drug delivery system

The objective of controlled release drug delivery includes two important aspects namely spatial placement and temporal delivery of drug. Spatial placement relates to targeting a drug to a specific organ or tissue, while temporal delivery refers to controlling the rate of drug delivery to the target tissue.
Oral controlled release dosage forms have been developed over the past three decades due to their considerable therapeutic advantages such as ease of administration, patient compliance and flexibility in formulation. However, this approach is be filled with several physiological difficulties such as inability to restrain and locate the controlled drug delivery system within the desired region of the gastrointestinal tract (GIT) due to variable motility and relatively brief gastric emptying time (GET) in humans which normally averages $2-3 \mathrm{~h}$ through the major absorption zone, i.e., stomach and upper part of the intestine can result in incomplete drug release from the drug delivery system leading to reduced efficacy of the administered dose.

The objective in designing a controlled release system is to deliver the drug at a rate necessary to achieve and maintain a constant drug blood level. This rate should be similar to that achieved by continuous intravenous infusion where a drug is provided to the patient at a rate just equal to its rate of elimination. This implies that the rate of delivery must be independent of the amount of drug remaining in the dosage form and constant over time, i.e., release from the dosage form should follow zeroorder kinetics.

\section{Aim and Objective}

- Aim of the study is to formulate Aceclofenac bioadhesive extended release microspheres using different polymers. 
- To formulate the Aceclofenac bioadhesive extended release microspheres using different polymers like sodium alginate, Guar Gum, Locust Bean Gum, Xanthan Gum.

- To choose the better formulation among the prepared formulations which shows better release and bioadhesion.

\section{Preformulation Studies}

\section{Spectroscopic Studies}

Preparation of 0.1N HCl (pH 1.2)

Take $8 \mathrm{ml}$ of $\mathrm{HCl}$ in a $1000 \mathrm{ml}$ volumetric flask and make up the volume with distilled water

\section{Determination of $\mathrm{\lambda Max}$ :}

Stock solution $(1000 \mu \mathrm{g} / \mathrm{ml})$ of Aceclofenac was prepared in methanol. This solution was appropriately diluted with $0.1 \mathrm{~N} \mathrm{HCl}(\mathrm{pH} 1.2)$ and 6.8 $\mathrm{pH}$ phosphate buffer to obtain a concentration of $10 \mu \mathrm{g} / \mathrm{ml}$. The resultant solution was scanned in the range of $200 \mathrm{~nm}$ to $400 \mathrm{~nm}$ on UV-Visible spectrophotometer. The drug exhibited a $\lambda \max$ at $252 \mathrm{~nm}$ and $254 \mathrm{~nm}$.

\section{Preparation of Standard Calibration Curve of Aceclofenac:}

- $10 \mathrm{mg}$ of Aceclofenac was accurately weighed and dissolved in $10 \mathrm{ml}$ of methanol (Stock Solution-I) to get a concentration of $1000 \mu \mathrm{g} / \mathrm{ml}$.

- From the stock solution- I,1ml of aliquots was taken and suitably diluted with $0.1 \mathrm{~N} \mathrm{HCl}$ (Stock Solution-II) to get concentrations of $100 \mu \mathrm{g} / \mathrm{ml}$.

- $\quad$ From the stock solution- II,aliquots were taken and suitably diluted with $0.1 \mathrm{~N} \mathrm{HCl}(\mathrm{pH} 1.2)$ to get concentrations in the range of 2 to $10 \mu \mathrm{g} / \mathrm{ml}$. The absorbance of these samples were analyzed by using UV-Visible Spectrophotometer at $252 \mathrm{~nm}$ against reference solution $0.1 \mathrm{~N} \mathrm{HCl}(\mathrm{pH}$ 1.2). The same procedure is repeated with $6.8 \mathrm{pH}$ phosphate buffer also

\section{The Linear Regression Analysis:}

The linear regression analysis was done on Absorance points. The standard calibration curve obtained had a Correlation Coefficient of 0.998 with of slope of 0.028 and intercept of 0.004 .

\section{Compatibility Studies}

\begin{tabular}{|l|l|l|l|}
\hline S. No. & Formulation Code & Drug:Polymer Ratio & Polymer Ratio \\
\hline 1 & $\mathbf{T}_{\mathbf{1}}$ & $\mathbf{1 : 2 . 5}$ & Na alginate : Guar Gum(1.5:0.5) \\
\hline 2 & $\mathbf{T}_{\mathbf{2}}$ & $\mathbf{1 : 3}$ & Na alginate : Guar Gum(2:1) \\
\hline 3 & $\mathbf{T}_{\mathbf{3}}$ & $\mathbf{1 : 3 . 5}$ & Na alginate : Guar Gum(2.5:1) \\
\hline 4 & $\mathbf{T}_{\mathbf{4}}$ & $\mathbf{1 : 4}$ & Na alginate : Guar Gum $(3: 1)$ \\
\hline 5 & $\mathbf{T}_{\mathbf{5}}$ & $\mathbf{1 : 2 . 5}$ & Na alginate: Locust Bean Gum $(1.5: 0.5)$ \\
\hline 6 & $\mathbf{T}_{\mathbf{6}}$ & $\mathbf{1 : 3}$ & Na alginate: Locust Bean Gum $(2: 1)$ \\
\hline 7 & $\mathbf{T}_{\mathbf{7}}$ & $\mathbf{1 : 3 . 5}$ & Na alginate: Locust Bean Gum $(2.5: 1)$ \\
\hline 8 & $\mathbf{T}_{\mathbf{8}}$ & $\mathbf{1 : 4}$ & Na alginate: Locust Bean Gum $(3: 1)$ \\
\hline 9 & $\mathbf{T}_{\mathbf{9}}$ & $\mathbf{1 : 2 . 5}$ & Na alginate: Xanthan gum $(1.5: 0.5)$ \\
\hline 10 & $\mathbf{T}_{\mathbf{1 0}}$ & $\mathbf{1 : 3}$ & Na alginate: Xanthan gum $(2: 1)$ \\
\hline 11 & $\mathbf{T}_{\mathbf{1 1}}$ & $\mathbf{1 : 3 . 5}$ & Na alginate: Xanthan gum $(2.5: 1)$ \\
\hline 12 & $\mathbf{T}_{\mathbf{1 2}}$ & $\mathbf{1 : 4}$ & Na alginate: Xanthan gum $(3: 1)$ \\
\hline
\end{tabular}

A proper design and formulation of a dosage form requires considerations of the physical, chemical and biological characteristics of both drug and excipients used in fabrication of the product. Compatibility must be established between the active ingredient and other excipients to produce a stable, efficacious, attractive and safe product. If the excipient(s) are new and if no previous literature regarding the use of that particular excipient with an active ingredient is available, then compatibility studies are of paramount importance. Hence, before producing the actual formulation, compatibility of Aceclofenac with different polymers and other excipients was tested using the Fourier Transform Infrared Spectroscopy (FT-IR) technique.

\section{Fourier Transform Infrared Spectroscopy (Ft-Ir):}

In order to check the integrity (Compatibility) of drug in the formulation,FT-IR spectra of the formulations along with the drug and other excipients were obtained and compared using Shimadzu FT-IR 8400 spectrophotometer. In the present study, Potassium bromide(KBr) pellet method was employed. The samples were thoroughly blended with dry powdered potassium bromide crystals. The mixture was compressed to form a disc. The disc was placed in the spectrophotometer and the spectrum was recorded.The FT-IR spectra of the formulations were compared with the FT-IR spectra of the pure drug and the polymers.

\section{Method of Preparation}

\section{Ionotropic Gelation Method:}

Batches of microcapsules were prepared by ionotropic gelation method which involved reaction between sodium alginate and polycationic ions like calcium to produce a hydrogel network of calcium alginate. Sodium alginate and the mucoadhesive polymer were dispersed in purified water $(10 \mathrm{ml})$ to form a homogeneous polymer mixture. The API, Aceclofenac $(100 \mathrm{mg})$ were added to the polymer premix and mixed thoroughly with a stirrer to form a viscous dispersion. The resulting dispersion was then added through a $22 \mathrm{G}$ needle into calcium chloride ( $4 \% \mathrm{w} / \mathrm{v})$ solution. The addition was done with continuous stirring at 200rpm. The added droplets were retained in the calcium chloride solution for 30 minutes to complete the curing reaction and to produce rigid spherical microcapsules. The microcapsules were collected by decantation, and the product thus separated was washed repeatedly with purified water to remove excess calcium impurity deposited on the surface of microcapsules and then airdried.

Table 1: Prepared formulation of Bioadhesive Microcapsules 


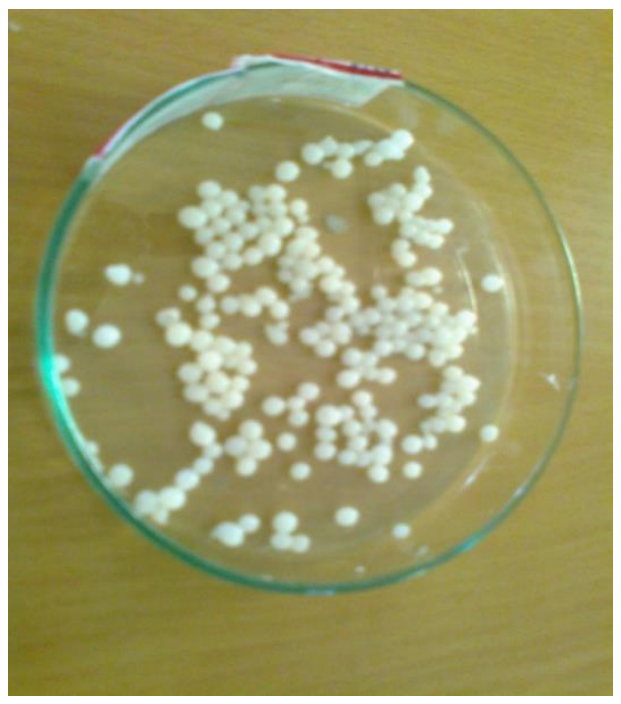

Figure 1. Photograph of prepared microcapsule

\section{Characterization of Microcapsules:}

\section{Percentage yield}

The percentage of production yield was calculated from the weight of dried microsphe-res recovered from each batch and the sum of the initial weight of starting materials. The percentage yield was calculated using the following formula:

$$
\text { Practical mass (Microcapsules) }
$$

$\%$ Yield= 100

Theoretical mass (Polymer + Drug)

\section{Drug entrapment efficiency:}

Microcapsules equivalent to $100 \mathrm{mg}$ of the drug Aceclofenac were taken for evaluation. The amount of drug entrapped was estimated by crushing the microcapsules. The powder was transferred to a $100 \mathrm{ml}$ volumetric flask and dissolved in $10 \mathrm{ml}$ of methanol and the volume was made up using simulated gastric fluid $\mathrm{pH}$ 1.2. After 24 hours the solution was filtered through Whatmann filter paper and the absorbance was measured after suitable dilution spectrophotometrically at $252 \mathrm{~nm}$. The amount of drug entrapped in the microcapsules was calculated by the following formula,

\section{Experimental Drug Content}

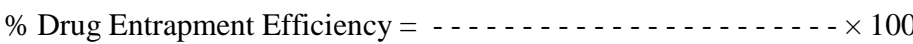

Theoretical Drug Content

\section{Particle size analysis:}

Samples of the microparticles were analyzed for particle size by optical microscope. The instrument was calibrated and found that lunit of eyepiece micrometer was equal to $12.5 \mu \mathrm{m}$. Nearly about 100 Microparticles sizes were calculated under $45 \mathrm{x}$ magnification. The average particle size was determined by using the Edmondson's equation: nd

$$
\text { Dmean=---.- }
$$

Where,

$\mathrm{n}$ - Number of microcapsules observed

D - Mean size range

\section{Swelling study:}

Swelling ratio of different dried microcapsules were determined gravimetrically in simulated gastric fluid $\mathrm{pH} 1.2$.The microcapsules were removed periodically from the solution, blotted to remove excess surface liquid and weighed on balance. Swelling ratio (\% w/v) was determined from the following relationship:

$$
\text { Swelling ratio }=\ldots \ldots+\ldots \text { - }-\ldots \times 100
$$

Where W0 \& Wt are initial weight and Final weight of microcapsules respectively.

\section{Evaluation of mucoadhesive property:}

The mucoadhesive property of microcapsules was evaluated by an in vitro adhesion testing method known as wash-off method. Freshly excised pieces of goat stomach mucous were mounted on to glass slides with cotton thread. About 20 microcapsules were spread on to each prepared glass slide and immediately thereafter the slides were hung to USP II tablet disintegration test, when the test apparatus was operated, the sample is subjected to slow up and down movement in simulated gastric fluid $\mathrm{pH}$ 1.2 at $37^{\circ} \mathrm{C}$ contained in a 1-litre vessel of the apparatus. At an interval of 1 hour up to 8 hours the machine is stopped and number of microcapsules still adhering to mucosal surface was counted.

Number of microcapsules adhered

$$
\text { \% Mucoadhesion= --- Number of microcapsules applied }
$$

\section{In vitro drug release study:}

The dissolution studies were performed in a fully calibrated eight station dissolution test apparatus $\left(37 \pm 0.5^{\circ} \mathrm{C}, 50 \mathrm{rpm}\right)$ using the USP type - I rotating basket method in simulated gastric fluid $\mathrm{pH} 1.2(900 \mathrm{ml})$. A quantity of accurately weighed microcapsules equivalent to $100 \mathrm{mg}$ Aceclofenac each formulation was employed in all dissolution studies. Aliquots of sample were withdrawn at predetermined intervals of time and analyzed for drug release by measuring the absorbance at $252 \mathrm{~nm}$. At the same time the volume withdrawn at each time intervals were replenished immediately with the same volume of fresh pre-warmed 
simulated gastric fluid $\mathrm{pH} 1.2$ maintaining sink conditions throughout the experiment.

\section{Results and Discussion}

\subsection{Preformulation Studies}

\subsubsection{Spectroscopic Studies}

A solution of $10 \mu \mathrm{g} / \mathrm{ml}$ of Aceclofenac was scanned in the range of 200 to $400 \mathrm{~nm}$. The drug exhibited a $\lambda \max$ at $252 \mathrm{~nm}$ in simulated gastric fluid pH 1.2 and had good reproducibility. Correlation between the concentration and absorbance was found to be near to 0.998 , with a slope of 0.028 and intercept of 0.004 .

Calibration curve of Aceclofenac in simulated gastric fluid $\mathrm{pH} 1.2$

Determination of $\lambda$ max

\begin{tabular}{|c|c|}
\hline $\begin{array}{c}\text { Concentration } \\
(\boldsymbol{\mu g} / \mathbf{m l})\end{array}$ & Absorbance \\
\hline 2 & 0.051 \\
\hline 4 & 0.110 \\
\hline 6 & 0.163 \\
\hline 8 & 0.221 \\
\hline 10 & 0.290 \\
\hline
\end{tabular}

Table 4.1 shows the calibration curve data of Aceclofenac in simulated gastric fluid pH 1.2 at $252 \mathrm{~nm}$ and $254 \mathrm{~nm}$ in $6.8 \mathrm{pH}$ phosphate buffer.

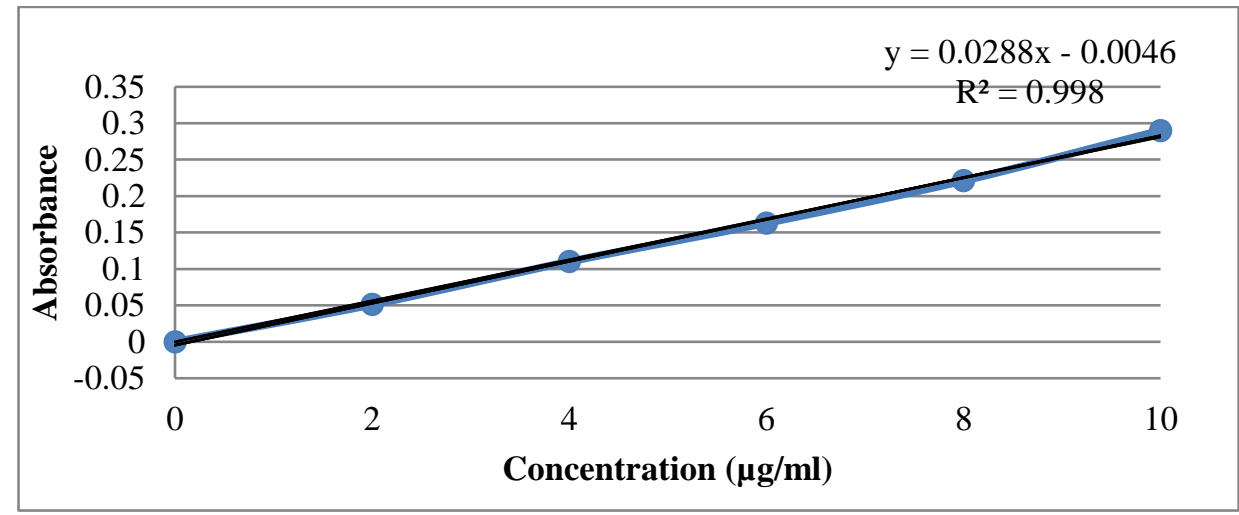

Figure 4.1(a): Standard graph of Aceclofenac in simulated gastric fluid pH 1.2

\begin{tabular}{|c|c|c|}
\hline S. No. & $\begin{array}{c}\text { Concentration } \\
(\boldsymbol{\mu g} / \mathbf{m l})\end{array}$ & Absorbance* $^{*}$ \\
\hline 1 & 2 & 0.193 \\
\hline 2 & 4 & 0.34 \\
\hline 3 & 6 & 0.461 \\
\hline 4 & 8 & 0.579 \\
\hline 5 & 10 & 0.709 \\
\hline \multicolumn{2}{|c|}{$\begin{array}{c}\text { Correlation Coefficient }=0.9985 \\
\mathrm{y}=0.0636 \mathrm{x}+0.0751\end{array}$} \\
\hline
\end{tabular}

Table 4.1 (b): Calibration curve data for Aceclofenac in 6.8pH phosphate buffer

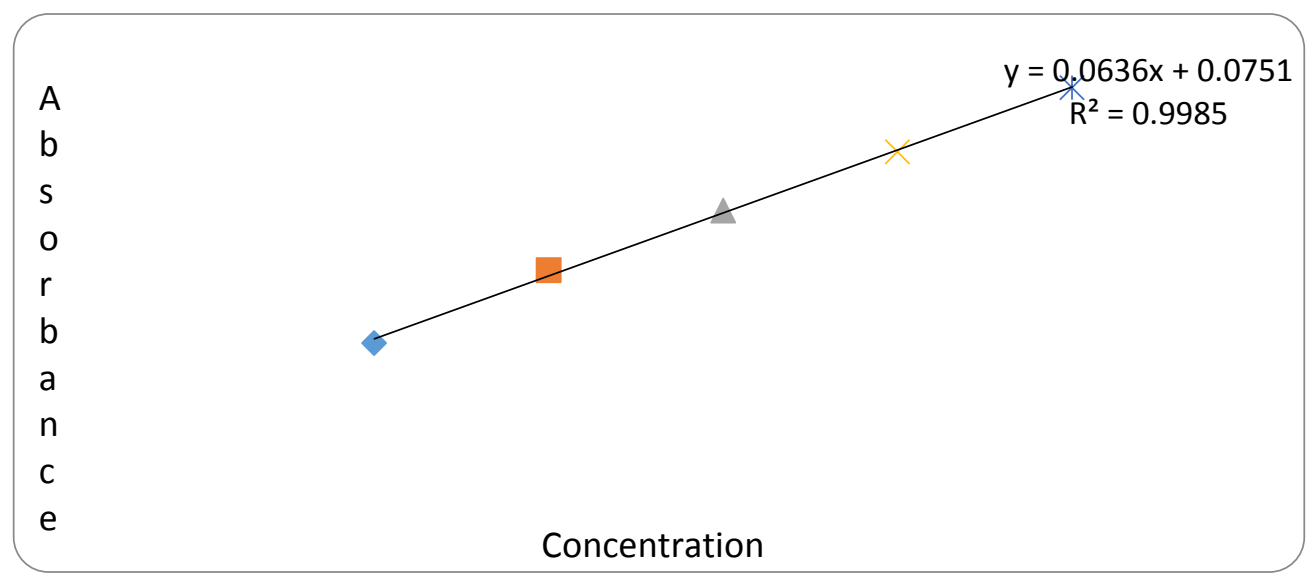

Figure 4.1(b): Standard graph of Aceclofenac in 6.8pH phosphate buffer 


\section{Compatibility Studies}

Drug polymer compatibility studies were carried out using Fourier Transform Infra-Red spectroscopy to establish any possible interaction of Drug with the polymers used in the formulation. The FT-IR spectra of the formulation were compared with the FTIR spectra of the pure drug.

\section{Evaluation and Characterisation of Microspheres}

\section{Percentage Yield}

It was observed that as the polymer ratio in the formulation increases, the product yield also increases. The low percentage yield in some formulations may be due to blocking of needle and wastage of the drugpolymer solution, adhesion of polymer solution to the magnetic bead and microspheres lost during the washing process. The percentage yield was found to be in the range of 80 to $88 \%$ for microspheres containing sodium alginate along with GUAR GUMas copolymer, 62.22 to $87 \%$ for microspheres containing sodium alginate along with LOCUST BEAN GUM as copolymer and 80 to $87.5 \%$ for microspheres containing sodium alginate along with XANTHAN GUMas copolymer. The percentage yield of the prepared microspheres is recorded in Table 6.2 and displayed in Figures 6.4 to 6.6 .

\section{Drug Entrapment Efficiency}

Percentage Drug entrapment efficiency of Aceclofenac ranged from 82.66 to $88.66 \%$ for microspheres containing sodium alginate along with GUAR GUMas copolymer, 53.2 to $76.66 \%$ for microspheres containing sodium alginate along with Locust Bean Gum as copolymer and 66.73 to $79.2 \%$ for microspheres containing sodium alginate along with Xanthan Gum as copolymer. The drug entrapment efficiency of the prepared microspheres increased progressively with an increase in proportion of the respective polymers. Increase in the polymer concentration increases the viscosity of the dispersed phase. The particle size increases exponentially with viscosity. The higher viscosity of the polymer solution at the highest polymer concentration would be expected to decrease the diffusion of the drug into the external phase which would result in higher entrapment efficiency. The \% drug entrapment efficiency of the prepared microspheres is displayed in Table 6.3, and displayed in Figures.

\begin{tabular}{|c|c|c|c|c|}
\hline S.No. & $\begin{array}{c}\text { Formulation } \\
\text { code }\end{array}$ & \% yield & Drug Content (mg) & $\begin{array}{c}\text { \% Drug entrapment } \\
\text { efficiency }\end{array}$ \\
\hline 1 & $\mathrm{~T}_{1}$ & 80 & 12.40 & 82.66 \\
\hline 2 & $\mathrm{~T}_{2}$ & 83.33 & 12.66 & 84.4 \\
\hline 3 & $\mathrm{~T}_{3}$ & 85 & 12.70 & 84.66 \\
\hline 4 & $\mathrm{~T}_{4}$ & 88 & 13.29 & 88.66 \\
\hline 5 & $\mathrm{~T}_{5}$ & 62.22 & 8.07 & 53.2 \\
\hline 6 & $\mathrm{~T}_{6}$ & 80 & 8.25 & 68.86 \\
\hline 7 & $\mathrm{~T}_{7}$ & 80 & 10.33 & 76.66 \\
\hline 8 & $\mathrm{~T}_{8}$ & 87 & 11.5 & 66.73 \\
\hline 9 & $\mathrm{~T}_{9}$ & 80 & 10.01 & 70 \\
\hline 10 & $\mathrm{~T}_{10}$ & 86 & 10.5 & 75 \\
\hline 11 & $\mathrm{~T}_{11}$ & 86.66 & 11.25 & 79.2 \\
\hline 12 & $\mathrm{~T}_{12}$ & 87.5 & 11.88 & \\
\hline
\end{tabular}

Table 4.2: Percentage yield and percentage drug entrapment efficiency of the prepared microspheres

\section{Particle Size Analysis}

The mean size increased with increasing polymer concentration which is due to a significant increase in the viscosity, thus leading to an increased droplet size and finally a higher microspheres size. Microspheres containing sodium alginate along with Guar gum as copolymer had a size range of $512 \mu \mathrm{m}$ to $826 \mu \mathrm{m}$, microspheres containing sodium alginate along with Locust Bean Gum as copolymer exhibited a size range between $517 \mu \mathrm{m}$ to $834 \mu \mathrm{m}$ and microspheres containing sodium alginate along with XANTHAN GUM as copolymer had a size range of $664 \mu \mathrm{m}$ to $903 \mu \mathrm{m}$. The particle size data is presented in Tables 6.3 to 6.13 and displayed in Figures. The effect of drug to polymer ratio on particle size is displayed in Figure. The particle size as well as \% drug entrapment efficiency of the microspheres increased with increase in the polymer concentration.

\begin{tabular}{|c|c|c|c|}
\hline $\begin{array}{c}\text { Particle Size Range } \\
(\mu \mathrm{m})\end{array}$ & $\begin{array}{c}\text { Midpoint Size Range } \\
(\mathrm{d})\end{array}$ & Frequency (n) & $\begin{array}{c}\text { Average Particle } \\
\text { Size }(\mu \mathrm{m})\end{array}$ \\
\hline $200-300$ & 250 & 9 & \multirow{3}{*}{$512 \mu \mathrm{m}$} \\
\hline $300-400$ & 350 & 13 & \multirow{2}{*}{} \\
\hline $400-500$ & 450 & 17 & \\
\hline $500-600$ & 550 & 29 & \\
\hline $600-700$ & 650 & 32 & \\
\hline & & $\sum \mathrm{n}=100$ & \\
\hline
\end{tabular}

Table 4.3: Particle size data of $T_{1}$

\begin{tabular}{|c|c|c|c|}
\hline $\begin{array}{l}\text { Particle Size Range } \\
\qquad(\mu \mathrm{m})\end{array}$ & $\begin{array}{l}\text { Midpoint Size Range } \\
\text { (d) }\end{array}$ & Frequency (n) & $\begin{array}{c}\text { Average Particle } \\
\text { Size }(\mu \mathrm{m})\end{array}$ \\
\hline $300-400$ & 350 & 15 & \multirow{6}{*}{$617 \mu \mathrm{m}$} \\
\hline $400-500$ & 450 & 13 & \\
\hline $500-600$ & 550 & 18 & \\
\hline $600-700$ & 650 & 12 & \\
\hline $700-800$ & 750 & 28 & \\
\hline $800-900$ & 850 & 14 & \\
\hline
\end{tabular}


\begin{tabular}{|l|l|l|}
\hline & & $\sum \mathrm{n}=100$ \\
\hline
\end{tabular}

Table 4.4: Particle size data of $T_{2}$

\begin{tabular}{|l|l|l|c|}
\hline $\begin{array}{c}\text { Particle Size Range } \\
(\mu \mathrm{m})\end{array}$ & $\begin{array}{c}\text { Midpoint Size Range } \\
(\mathrm{d})\end{array}$ & \multicolumn{1}{|c|}{ Frequency $(\mathrm{n})$} & $\begin{array}{c}\text { Average Particle } \\
\text { Size }(\mu \mathrm{m})\end{array}$ \\
\hline $400-500$ & 450 & 10 & \multirow{2}{*}{$711 \mu \mathrm{m}$} \\
\cline { 1 - 3 } $500-600$ & 550 & 12 & \\
\cline { 1 - 3 } & 650 & 18 & \\
\hline $700-700$ & 750 & 27 & \\
\hline $800-900$ & 850 & 33 & $\sum \mathrm{n}=100$ \\
\hline
\end{tabular}

Table 4.5: Particle size data of $T_{3}$

\begin{tabular}{|c|c|c|c|}
\hline $\begin{array}{c}\text { Particle Size Range } \\
(\mu \mathrm{m})\end{array}$ & $\begin{array}{l}\text { Midpoint Size Range } \\
\text { (d) }\end{array}$ & Frequency (n) & $\begin{array}{c}\text { Average Particle } \\
\text { Size }(\mu \mathrm{m})\end{array}$ \\
\hline $500-600$ & 550 & 6 & \multirow{6}{*}{$826 \mu \mathrm{m}$} \\
\hline $600-700$ & 650 & 12 & \\
\hline $700-800$ & 750 & 16 & \\
\hline $800-900$ & 850 & 32 & \\
\hline $900-1000$ & 950 & 34 & \\
\hline & & $\sum n=100$ & \\
\hline
\end{tabular}

Table 4.6: Particle size data of $T_{4}$

\begin{tabular}{|c|c|c|c|}
\hline $\begin{array}{l}\text { Particle Size Range } \\
\qquad(\mu \mathrm{m})\end{array}$ & $\begin{array}{l}\text { Midpoint Size Range } \\
\text { (d) }\end{array}$ & Frequency (n) & $\begin{array}{c}\text { Average Particle } \\
\text { Size }(\mu \mathrm{m})\end{array}$ \\
\hline $200-300$ & 250 & 8 & \multirow{6}{*}{$517 \mu \mathrm{m}$} \\
\hline $300-400$ & 350 & 12 & \\
\hline $400-500$ & 450 & 18 & \\
\hline $500-600$ & 550 & 29 & \\
\hline $600-700$ & 650 & 33 & \\
\hline & & $\sum n=100$ & \\
\hline
\end{tabular}

Table 4.7: Particle size data of 5

\begin{tabular}{|c|c|c|c|}
\hline $\begin{array}{l}\text { Particle Size Range } \\
(\mu \mathrm{m})\end{array}$ & $\begin{array}{l}\text { Midpoint Size Range } \\
\text { (d) }\end{array}$ & Frequency (n) & $\begin{array}{c}\text { Average Particle } \\
\text { Size }(\mu \mathrm{m})\end{array}$ \\
\hline $300-400$ & 350 & 12 & \multirow{7}{*}{$642 \mu \mathrm{m}$} \\
\hline $400-500$ & 450 & 11 & \\
\hline $500-600$ & 550 & 15 & \\
\hline $600-700$ & 650 & 14 & \\
\hline $700-800$ & 750 & 31 & \\
\hline $800-900$ & 850 & 17 & \\
\hline & & $\sum n=100$ & \\
\hline
\end{tabular}

Table 4.8: Particle size data of $T_{6}$

\begin{tabular}{|c|c|c|c|}
\hline $\begin{array}{l}\text { Particle Size Range } \\
\qquad(\mu \mathrm{m})\end{array}$ & $\begin{array}{c}\text { Midpoint Size Range } \\
\text { (d) }\end{array}$ & Frequency (n) & $\begin{array}{c}\text { Average Particle } \\
\text { Size }(\mu \mathrm{m})\end{array}$ \\
\hline $400-500$ & 450 & 6 & \multirow{7}{*}{$792 \mu \mathrm{m}$} \\
\hline $500-600$ & 550 & 10 & \\
\hline $600-700$ & 650 & 8 & \\
\hline $700-800$ & 750 & 19 & \\
\hline $800-900$ & 850 & 26 & \\
\hline $900-1000$ & 950 & 31 & \\
\hline & & $\sum \mathrm{n}=100$ & \\
\hline
\end{tabular}

Table 4.9: Particle size data of $T_{7}$

\begin{tabular}{|c|c|c|c|}
\hline $\begin{array}{l}\text { Particle Size Range } \\
(\mu \mathrm{m})\end{array}$ & $\begin{array}{l}\text { Midpoint Size Range } \\
\text { (d) }\end{array}$ & Frequency (n) & $\begin{array}{c}\text { Average Particle } \\
\text { Size }(\mu \mathrm{m})\end{array}$ \\
\hline $500-600$ & 550 & 6 & \\
\hline $600-700$ & 650 & 11 & \\
\hline $700-800$ & 750 & 13 & \\
\hline
\end{tabular}




\begin{tabular}{|c|c|c|c|}
\hline $800-900$ & 850 & 33 & \multirow{2}{*}{$834 \mu \mathrm{m}$} \\
\hline $900-1000$ & 950 & 37 & \\
\hline & & $\sum \mathrm{n}=100$ & \\
\hline
\end{tabular}

Table 4.10: Particle size data of $T_{8}$

\begin{tabular}{|c|c|c|c|}
\hline $\begin{array}{l}\text { Particle Size Range } \\
(\mu \mathrm{m})\end{array}$ & $\begin{array}{l}\text { Midpoint Size Range } \\
\text { (d) }\end{array}$ & Frequency (n) & $\begin{array}{l}\text { Average Particle } \\
\text { Size }(\mu \mathrm{m})\end{array}$ \\
\hline $400-500$ & 450 & 18 & \multirow{6}{*}{$664 \mu \mathrm{m}$} \\
\hline $500-600$ & 550 & 19 & \\
\hline $600-700$ & 650 & 18 & \\
\hline $700-800$ & 750 & 21 & \\
\hline $800-900$ & 850 & 24 & \\
\hline & & $\sum n=100$ & \\
\hline
\end{tabular}

Table 4.11: Particle size data of $T_{9}$

\begin{tabular}{|c|c|c|c|}
\hline $\begin{array}{l}\text { Particle Size Range } \\
\qquad(\mu \mathrm{m})\end{array}$ & $\begin{array}{l}\text { Midpoint Size Range } \\
\text { (d) }\end{array}$ & Frequency (n) & $\begin{array}{c}\text { Average Particle } \\
\text { Size }(\mu \mathrm{m})\end{array}$ \\
\hline $400-500$ & 450 & 8 & \multirow{7}{*}{$774 \mu \mathrm{m}$} \\
\hline $500-600$ & 550 & 12 & \\
\hline $600-700$ & 650 & 10 & \\
\hline $700-800$ & 750 & 17 & \\
\hline $800-900$ & 850 & 24 & \\
\hline $900-1000$ & 950 & 29 & \\
\hline & & $\sum n=100$ & \\
\hline
\end{tabular}

Table 4.12: Particle size data of $T_{10}$

\begin{tabular}{|c|c|c|c|}
\hline $\begin{array}{c}\text { Particle Size Range } \\
(\mu \mathrm{m})\end{array}$ & $\begin{array}{c}\text { Midpoint Size Range } \\
(\mathrm{d})\end{array}$ & Frequency $(\mathrm{n})$ & $\begin{array}{c}\text { Average Particle Size } \\
(\mu \mathrm{m})\end{array}$ \\
\hline $500-600$ & 550 & 8 & \multirow{2}{*}{$814 \mu \mathrm{m}$} \\
\hline $600-700$ & 650 & 14 & \\
\hline $700-800$ & 750 & 17 & \\
\hline $800-900$ & 850 & 28 & \\
\hline $900-1000$ & 950 & 33 & \\
\hline & & $\sum \mathrm{n}=100$ & \\
\hline
\end{tabular}

Table 4.13: Particle size data of $T_{11}$

\begin{tabular}{|c|c|c|c|}
\hline $\begin{array}{c}\text { Particle Size Range } \\
(\mu \mathrm{m})\end{array}$ & $\begin{array}{c}\text { Midpoint Size Range } \\
(\mathrm{d})\end{array}$ & Frequency $(\mathrm{n})$ & $\begin{array}{c}\text { Average Particle SIZE } \\
(\mu \mathrm{m})\end{array}$ \\
\hline $600-700$ & 650 & 2 & \multirow{2}{*}{$903 \mu \mathrm{m}$} \\
\cline { 1 - 3 } & 750 & 3 & \multirow{2}{*}{} \\
\hline $800-800$ & 850 & 35 & \\
\hline $900-1000$ & 950 & 60 & \\
\hline & & $\sum \mathrm{n}=100$ & \\
\hline
\end{tabular}

Table 4.14: Particle size data of $T_{12}$

The swelling ratio is expressed as the percentage of water in the hydrogel at any instant during swelling. Swell ability is an important characteristic as it affects mucoadhesion as well as drug release profiles of polymeric drug delivery systems. Swell ability is an indicative parameter for rapid availability of drug solution for diffusion with greater flux. Swell ability data revealed that amount of polymer plays an important role in solvent transfer. It can be concluded from the data shown in Table 6.14 that with an increase in polymer concentration, the percentage of swelling also increases. Thus we can say that amount of polymer directly affects the swelling ratio. As the polymer to drug ratio increased, the percentage of swelling increased from 28 to $85 \%$ for microspheres containing sodium alginate along with GUAR Gum as copolymer, 24 to $64 \%$ for microspheres containing sodium alginate along with Locust Bean Gum as copolymer and 31 to 85 for microspheres containing sodium alginate along with Xanthan Gum as copolymer. The percentage of swelling of the prepared microspheres is displayed in Figures. The effect of drug to polymer ratio on percentage swelling is displayed in Figure.

\begin{tabular}{|c|c|c|c|c|}
\hline S.NO. & $\begin{array}{c}\text { Formulation } \\
\text { Code }\end{array}$ & $\begin{array}{c}\text { Initial } \\
(\mathrm{Wt})\end{array}$ & $\begin{array}{c}\text { Final } \\
(\mathrm{Wt})\end{array}$ & $\begin{array}{c}\text { Percentage } \\
\text { Swelling }\end{array}$ \\
\hline 1 & $\mathrm{~T}_{1}$ & 10 & 12.8 & 28 \\
\hline 2 & $\mathrm{~T}_{2}$ & 10 & 14.2 & 42 \\
\hline 3 & $\mathrm{~T}_{3}$ & 10 & 16.2 & 62 \\
\hline 4 & $\mathrm{~T}_{4}$ & 10 & 18.5 & 85 \\
\hline 5 & $\mathrm{~T}_{5}$ & 10 & 12.4 & 24 \\
\hline
\end{tabular}




\begin{tabular}{|c|c|c|c|c|}
\hline 6 & $\mathrm{~T}_{6}$ & 10 & 13.9 & 39 \\
\hline 7 & $\mathrm{~T}_{7}$ & 10 & 15.5 & 55 \\
\hline 8 & $\mathrm{~T}_{8}$ & 10 & 16.4 & 64 \\
\hline 9 & $\mathrm{~T}_{9}$ & 10 & 13.1 & 31 \\
\hline 10 & $\mathrm{~T}_{10}$ & 10 & 15.3 & 53 \\
\hline 11 & $\mathrm{~T}_{11}$ & 10 & 16.7 & 67 \\
\hline 12 & $\mathrm{~T}_{12}$ & 10 & 18.5 & 85 \\
\hline
\end{tabular}

Table 4.15: Percentage swelling of the prepared microspheres

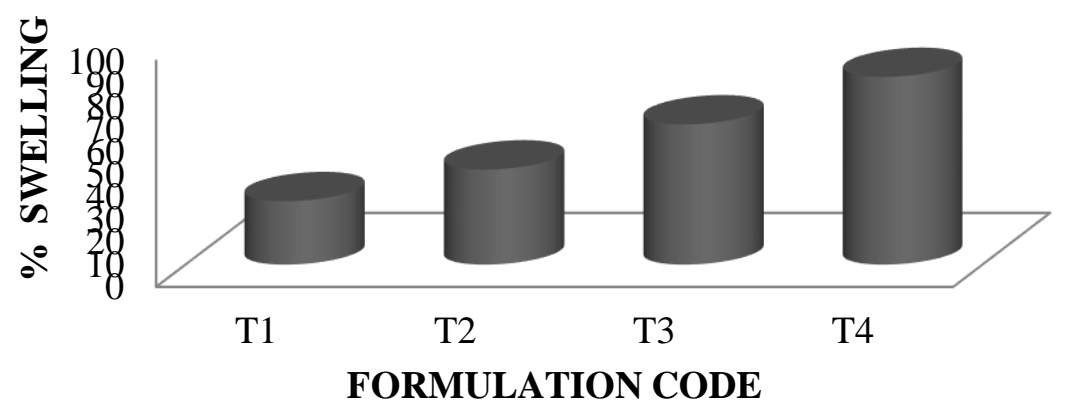

Figure 4.2: Percentage swelling of microspheres containing sodium alginate along with Guar Gumas copolymer

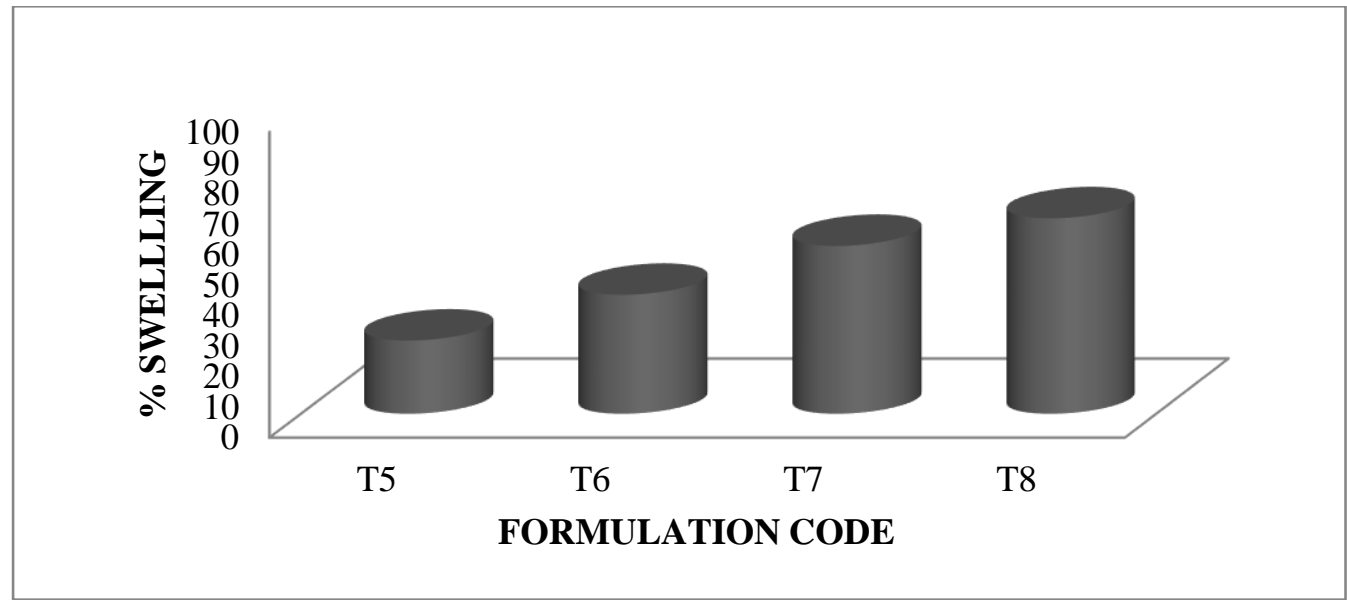

Figure 4.3: Percentage swelling of microspheres containing sodium alginate along with Locust Bean Gum as copolymer

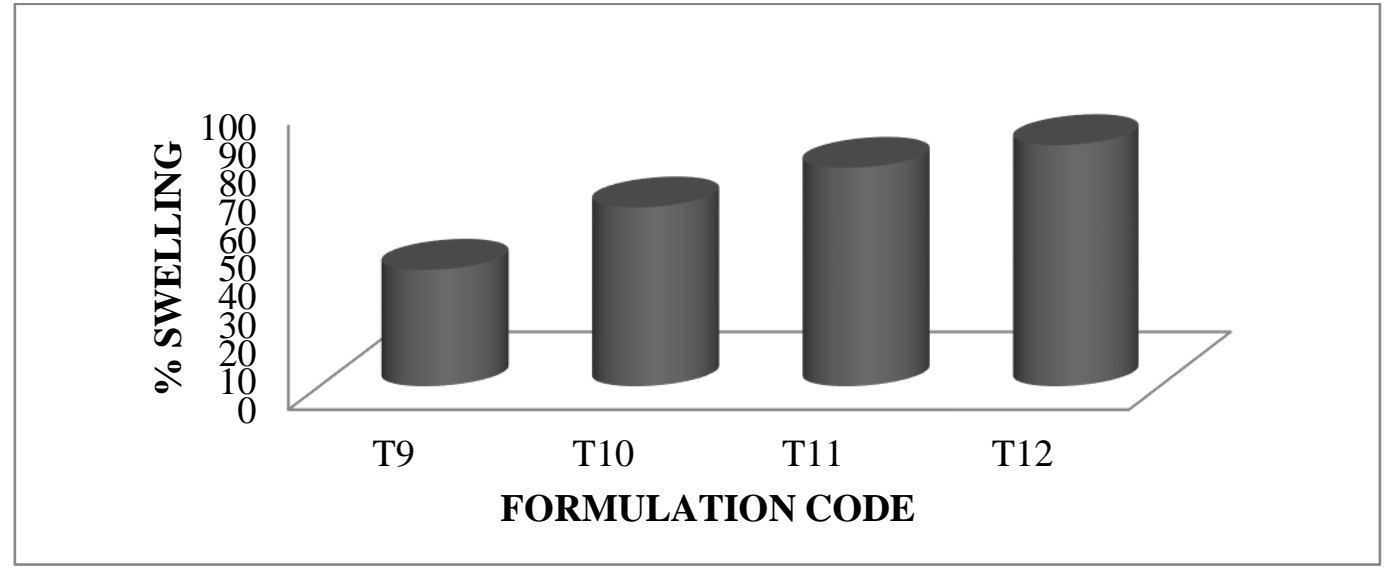

Figure 4.4: Percentage swelling of microspheres containing sodium alginate along with XANTHAN Gumas copolymer 


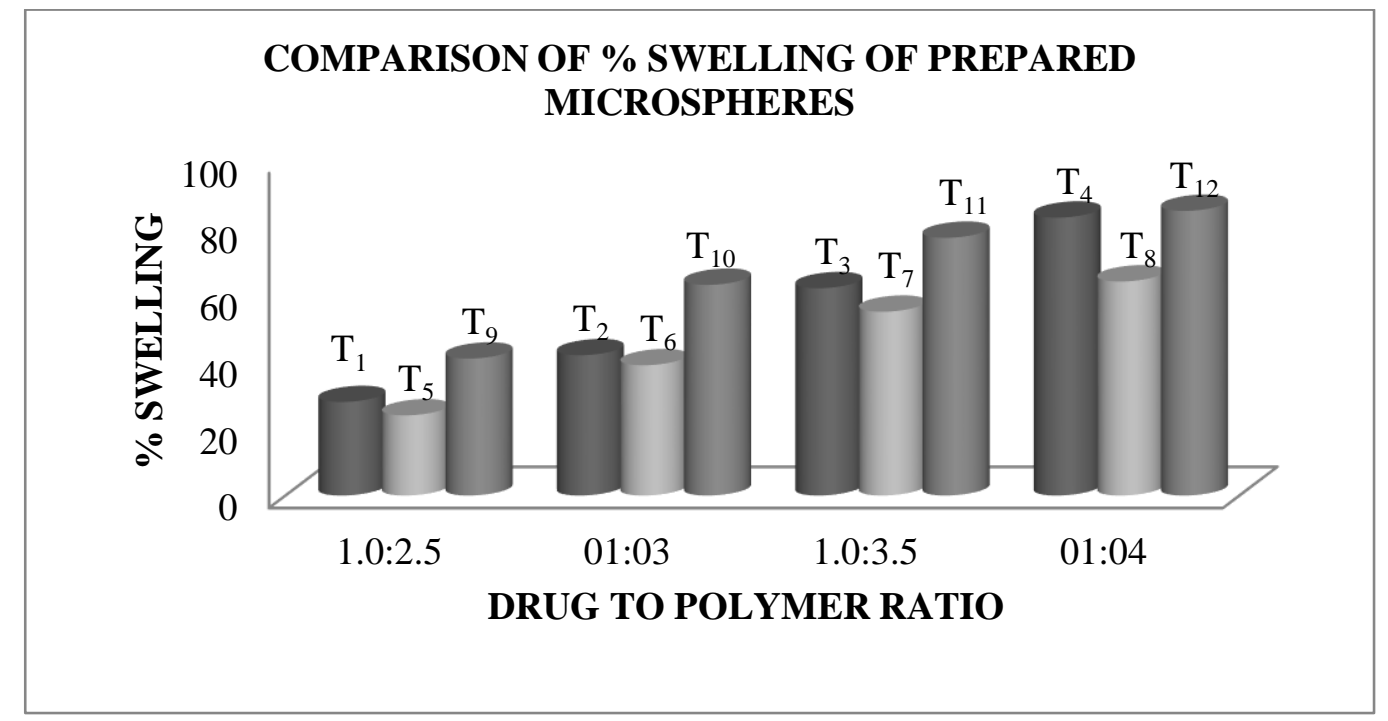

Figure 4.5: Comparison of percentage swelling of prepared microspheres

\section{In-Vitro Mucoadhesion Test}

As the polymer to drug ratio increased, microspheres containing sodium alginate along with Guar Gum as copolymer exhibited \% mucoadhesion ranging from 65 to $85 \%$, microspheres containing sodium alginate along with Locust Bean Gum as copolymer exhibited \% mucoadhesion ranging from 60 to $75 \%$ and microspheres containing sodium alginate along with
Xanthan Gum as copolymer exhibited \% mucoadhesion ranging from 60 to $80 \%$.

The rank of order of mucoadhesion is Guar Gum> Xanthan Gum > Locust Bean Gum. The results of in-vitro mucoadhesion test are compiled in Table 6.15. Effect of polymer proportion on $\%$ mucoadhesion is depicted in Figures 6.14 to 6.16 and comparative depiction of $\%$ mucoadhesion is depicted in Figure 6.17.

\begin{tabular}{|c|c|c|c|c|}
\hline \multirow{2}{*}{ S.NO. } & \multirow{2}{*}{$\begin{array}{c}\text { Formulation } \\
\text { Code }\end{array}$} & \multicolumn{2}{|c|}{ No. of Microspheres } & \multirow{2}{*}{ Percentage Mucoadhesion } \\
\cline { 2 - 4 } & $\mathrm{T}_{1}$ & Initial & Final & 65 \\
\hline 1 & $\mathrm{~T}_{2}$ & 20 & 13 & 70 \\
\hline 2 & $\mathrm{~T}_{3}$ & 20 & 15 & 75 \\
\hline 3 & $\mathrm{~T}_{4}$ & 20 & 17 & 85 \\
\hline 4 & $\mathrm{~T}_{5}$ & 20 & 12 & 60 \\
\hline 5 & $\mathrm{~T}_{6}$ & 20 & 13 & 65 \\
\hline 6 & $\mathrm{~T}_{7}$ & 20 & 14 & 75 \\
\hline 7 & $\mathrm{~T}_{8}$ & 20 & 15 & 60 \\
\hline 8 & $\mathrm{~T}_{9}$ & 20 & 12 & 70 \\
\hline 9 & $\mathrm{~T}_{10}$ & 20 & 14 & 75 \\
\hline 10 & $\mathrm{~T}_{11}$ & 20 & 15 & 80 \\
\hline 11 & $\mathrm{~T}_{12}$ & 20 & 16 & \\
\hline 12 & & & & \\
\hline
\end{tabular}

Table 4.16: Percentage mucoadhesion of the prepared microspheres

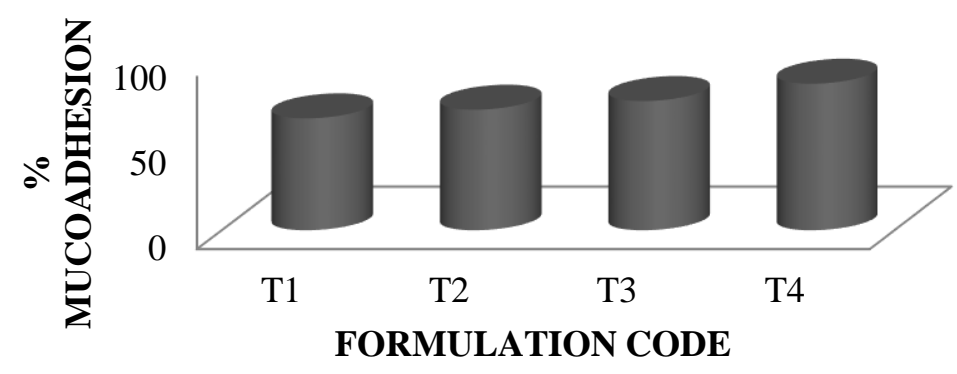




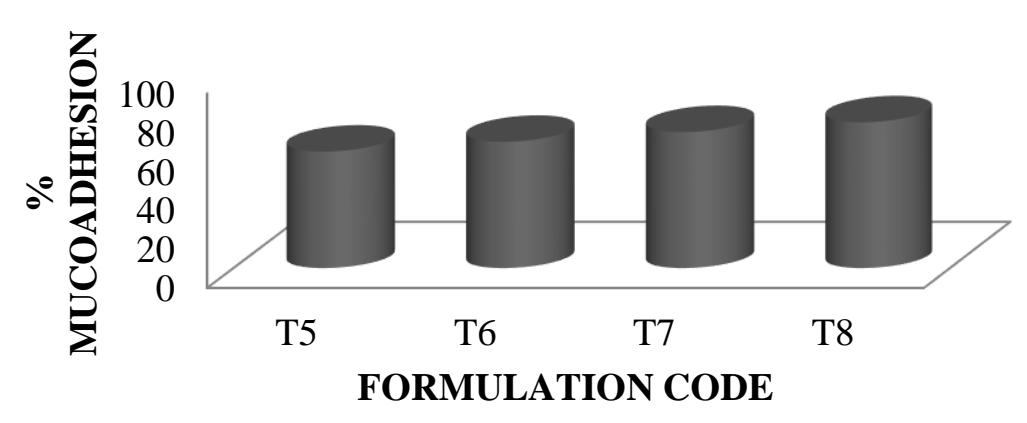

Figure 4.7: Percentage mucoadhesion of microspheres containing sodium alginate along with Locust Bean Gum as copolymer

Figure 4.8: Percentage mucoadhesion of microspheres containing sodium alginate along with Xanthan Gumas copolymer

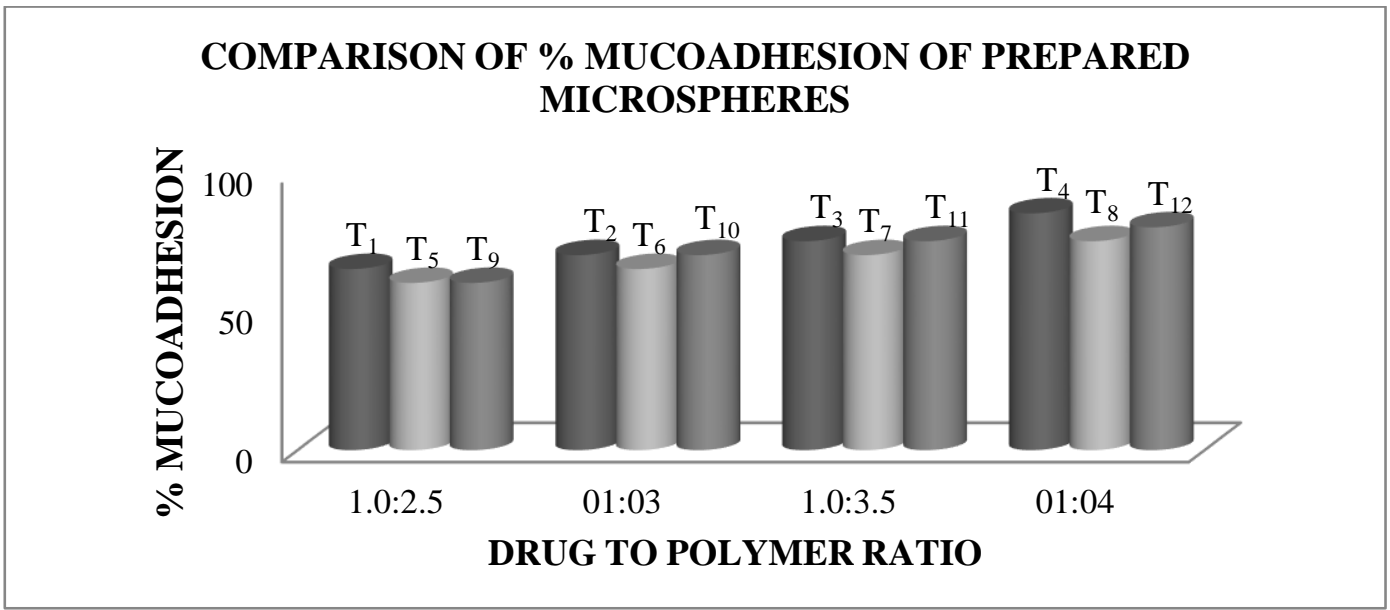

Figure 4.9: Comparison of percentage mucoadhesion of prepared microspheres

\section{In-Vitro Drug Release Studies}

Dissolution studies of all the formulations were carried out using dissolution apparatus USP type I. The dissolution studies were conducted by using dissolution media, $\mathrm{pH}$ 1.2.for fisrt $2 \mathrm{hr}$ and then it was eplaced with $6.8 \mathrm{ph}$ phosphate buffer The results of the in-vitro dissolution studies of formulations $\mathrm{T} 1$ to $\mathrm{T} 4, \mathrm{~T} 5$ to $\mathrm{T} 8$ and $\mathrm{T} 9$ to $\mathrm{T} 12$ are shown in table. The plots of Cumulative percentage drug release Vs Time. Figure shows the comparison of \% CDR for formulations T1 to T4, figure for formulations T5 to T8 and figure 6.26 for formulations T9 to T12. Korsmeyer-Peppas plots of Aceclofenac microspheres formulations T1 to T12 are displayed in figures.

The formulations T1, T2, T3 and T4 containing Sodium alginate along with GUAR GUMas copolymer showed a maximum release of $92.66 \%$ after 9 hours, $90.66 \%$ after 10 hours, $90.6 \%$ after 11 hours and $94.66 \%$ after 12 hours respectively.

The formulations T5, T6, T7 and T8 containing Sodium alginate along with Locust Bean Gum as copolymer showed a maximum release of $92.22 \%$ after 9 hours, $91.33 \%$ after 10 hours, $89.55 \%$ after 11 hours and $90.66 \%$ after 12 hours respectively.

The formulations T9, T10, T11 and T12 containing Sodium alginate along with Xanthan Gumas copolymer showed a maximum release of $92.6 \%$ after 9 hours, $91.3 \%$ after 10 hours, $90 \%$ after 11 hours and $92.44 \%$ after 12 hours respectively.

This shows that more sustained release was observed with the increase in percentage of polymers. As the polymer to drug ratio was increased the 
extent of drug release decreased. A significant decrease in the rate and extent of drug release is attributed to the increase in density of polymer matrix that results in increased diffusion path length which the drug molecules have to traverse. The releaseof the drug has been controlled by swelling control release mechanism. Additionally, the larger particle size at higher polymer concentration also restricted the total surface area resulting in slower release.

\begin{tabular}{|c|c|c|c|c|}
\hline \multirow{2}{*}{ TIME (h) } & \multicolumn{5}{|c|}{ CUMULATIVE PRECENT OF DRUG RELEASED } \\
\cline { 2 - 5 } & $\mathbf{T}_{\mathbf{1}}$ & $\mathbf{T}_{\mathbf{2}}$ & $\mathbf{T}_{\mathbf{3}}$ & $\mathbf{T}_{\mathbf{4}}$ \\
\hline $\mathbf{0}$ & 0 & 0 & 0 & 0 \\
\hline 1 & 24.88 & 21.11 & 18.66 & 15.88 \\
\hline 2 & 31.55 & 31.55 & 25.11 & 24.22 \\
\hline 3 & 42.44 & 39.77 & 35.44 & 32.66 \\
\hline 4 & 53.55 & 47.77 & 40.66 & 39.33 \\
\hline 5 & 62 & 56.66 & 52 & 47.55 \\
\hline 6 & 74.66 & 62.44 & 57.33 & 55.77 \\
\hline 7 & 83.55 & 69.55 & 63.11 & 61.77 \\
\hline 8 & 89.33 & 75.33 & 69.11 & 69.55 \\
\hline 9 & 92.66 & 84.66 & 75.33 & 77.55 \\
\hline 10 & 85.55 & 90.66 & 82.66 & 85.55 \\
\hline 11 & 80.22 & 84.22 & 90.66 & 90.66 \\
\hline 12 & 78.88 & 80.88 & 89.55 & 94.66 \\
\hline
\end{tabular}

Table 4.17: In-Vitro drug release data of Aceclofenac microspheres containing sodium alginate along with Guar Gum as copolymer

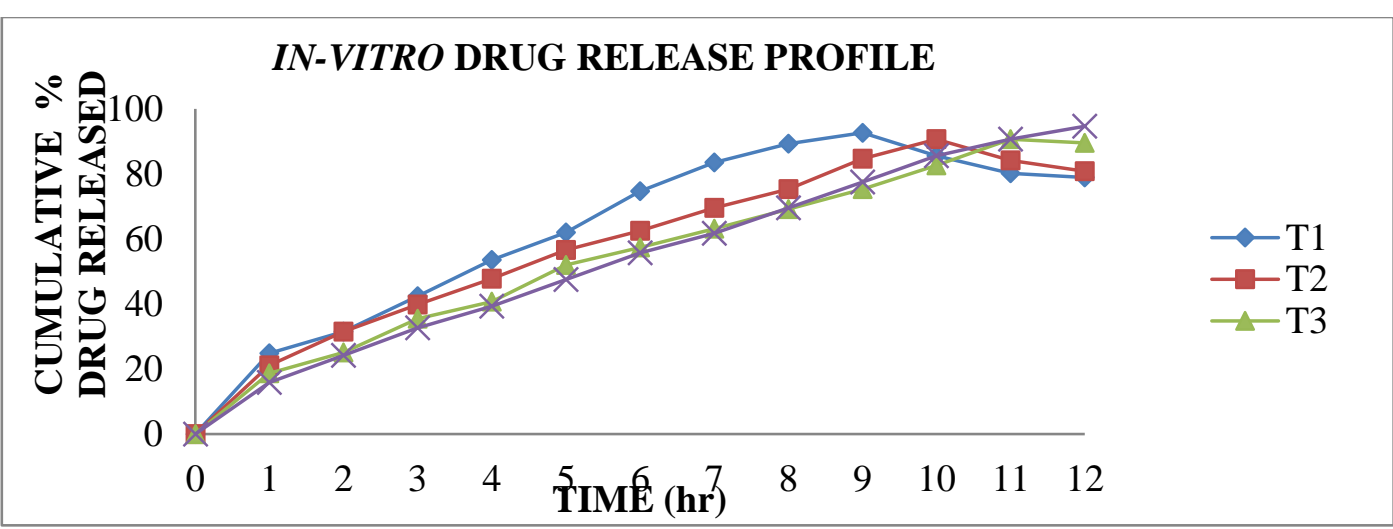

Figure 4.10: Comparison of In-Vitro drug release profile of Aceclofenac microspheres containing sodium alginate along with Guar Gum as copolymer

\begin{tabular}{|c|c|c|c|c|}
\hline \multirow{2}{*}{ TIME (h) } & \multicolumn{4}{|c|}{ CUMULATIVE PRECENT OF DRUG RELEASED } \\
\cline { 2 - 5 } & $\mathbf{T}_{\mathbf{5}}$ & $\mathbf{T}_{\mathbf{6}}$ & $\mathbf{T}_{\mathbf{7}}$ & $\mathbf{T}_{\mathbf{8}}$ \\
\hline $\mathbf{0}$ & 0 & 0 & 0 & 0 \\
\hline 1 & 27.77 & 22.44 & 18.44 & 17.11 \\
\hline 2 & 36.44 & 32.22 & 29.33 & 26.44 \\
\hline 3 & 43.77 & 40.88 & 39.55 & 37.55 \\
\hline 4 & 54.66 & 48.66 & 45.55 & 46.88 \\
\hline 5 & 64.01 & 57.55 & 57.33 & 55.77 \\
\hline 6 & 75.77 & 63.55 & 65.33 & 63.55 \\
\hline 7 & 84.65 & 70.44 & 71.55 & 71.33 \\
\hline 8 & 90 & 76.55 & 77.56 & 75.77 \\
\hline 9 & 92.22 & 85.55 & 81.55 & 79.77 \\
\hline 10 & 84.88 & 91.33 & 83.33 & 82.44 \\
\hline 11 & 79.55 & 85.77 & 89.55 & 86.88 \\
\hline 12 & 77.55 & 81.11 & 87.55 & 90.66 \\
\hline
\end{tabular}

Table 4.18: In-Vitro drug release data of Aceclofenac microspheres containing sodium alginate along with Locust Bean Gum as copolymer 


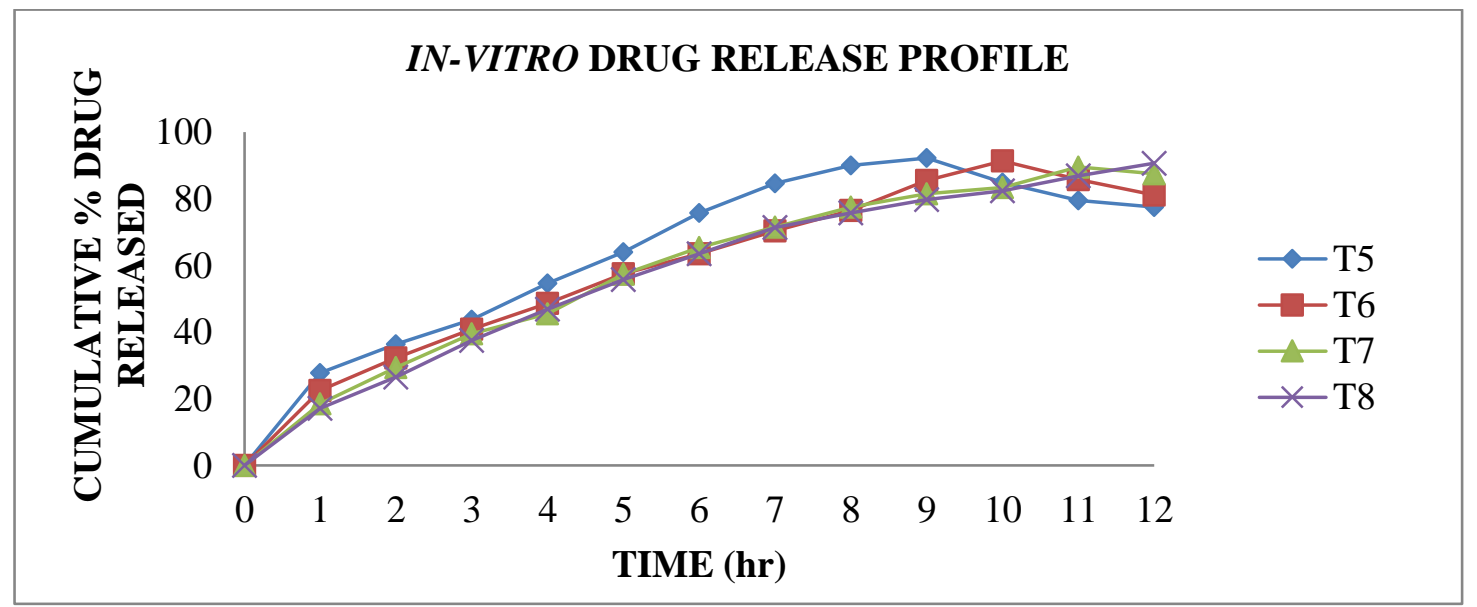

Figure 4.11 Comparison of In-Vitro drug release profile of Aceclofenac microspheres containing sodium alginate along with Locust Bean Gum as copolymer

\begin{tabular}{|c|c|c|c|c|}
\hline \multirow{2}{*}{ Time (h) } & \multicolumn{4}{|c|}{ Cumulative Percent of Drug Released } \\
\cline { 2 - 5 } & $\mathbf{T} 9$ & $\mathbf{T}_{\mathbf{1 0}}$ & $\mathbf{T}_{\mathbf{1 1}}$ & $\mathbf{T}_{\mathbf{1 2}}$ \\
\hline $\mathbf{0}$ & 0 & 0 & 0 & 0 \\
\hline 1 & 25.77 & 21.55 & 18.66 & 16.44 \\
\hline 2 & 35.33 & 31.77 & 26.55 & 27.11 \\
\hline 3 & 43.55 & 40.44 & 36.55 & 36.44 \\
\hline 4 & 54 & 48.44 & 43.66 & 45.55 \\
\hline 5 & 63.55 & 57.11 & 54.55 & 55.33 \\
\hline 6 & 75.33 & 63.11 & 62.33 & 63.11 \\
\hline 7 & 84 & 70.22 & 67.68 & 71.55 \\
\hline 8 & 89.77 & 76 & 73.55 & 76.44 \\
\hline 9 & 92.66 & 85.11 & 78.55 & 80.66 \\
\hline 10 & 85.11 & 91.33 & 83 & 85.55 \\
\hline 11 & 80.66 & 85.33 & 90 & 89.55 \\
\hline 12 & 78 & 81.11 & 87.55 & 92.44 \\
\hline
\end{tabular}

Table 4.19: In-Vitro drug release data of Aceclofenac microspheres containing sodium alginate along with Xanthan Gum as copolymer

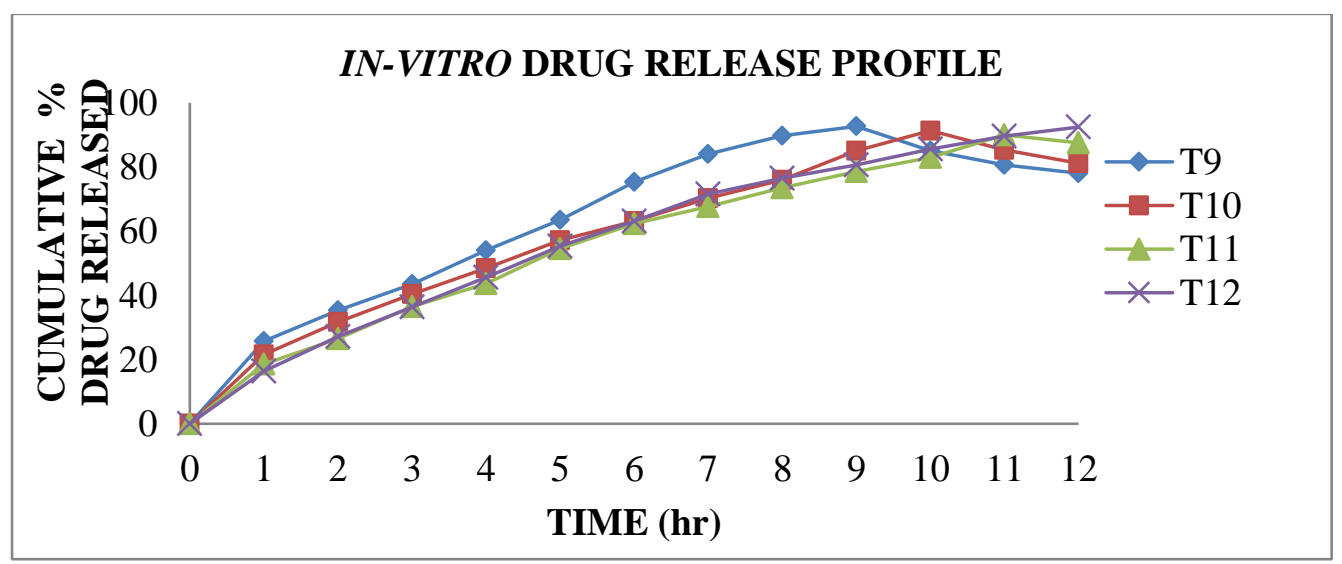

Figure 4.12: Comparison of In-Vitro drug release profile of Aceclofenac microspheres containing sodium alginate along with XANTHAN GUM as copolymer

\section{In-Vitro Drug Release Kinetics}

For understanding the mechanism of drug release and release rate kineti cs of the drug from dosage form, the invitro drug dissolution data obtained was fitted to various mathematical models such as zero order, First order, Higuchi matrix, and KrosmeyerPeppas model. The values are compiled in Table 6.21. The coefficient of determination $\left(\mathrm{R}^{2}\right)$ was used as an indicator of the best fitting for each of the models considered. The kinetic data analysis of all the formulations reached higher coefficient of determination with the Korsmeyer-Peppas model $\left(\mathrm{R}^{2}=0.914\right.$ to 0.996$)$ whereas release exponent value (n) ranged from 0.498 to 0.743 . From the coefficient of determination and release exponent values, it can be suggested that the mechanism of drug release follows Korsmeyer-Peppas model along with non-Fickian diffusion mechanism which leading to the conclusion that a release mechanism of drug followed combination of diffusion and spheres erosion. 


\begin{tabular}{|c|c|c|c|c|c|c|c|c|c|}
\hline \multirow{3}{*}{$\begin{array}{l}\text { Formulation } \\
\text { code }\end{array}$} & \multicolumn{9}{|c|}{ Release model } \\
\hline & \multicolumn{2}{|c|}{ Zero order } & \multicolumn{2}{|c|}{ First order } & \multicolumn{2}{|c|}{ Higuchi matrix } & \multicolumn{3}{|c|}{ Koresmeyer-peppas } \\
\hline & $\mathrm{K}$ & $\mathrm{R}^{2}$ & $\mathrm{~K}$ & $\mathrm{R}^{2}$ & $\mathrm{~K}$ & $\mathrm{R}^{2}$ & $\mathrm{n}$ & $\mathrm{K}$ & $\mathrm{R}^{2}$ \\
\hline $\mathrm{T}_{1}$ & 21.6 & 0.797 & 1.923 & 0.720 & -0.313 & 0.912 & 0.556 & 1.388 & 0.925 \\
\hline $\mathrm{T}_{2}$ & 16.39 & 0.908 & 1.991 & 0.890 & -3.945 & 0.970 & 0.595 & 1.326 & 0.983 \\
\hline $\mathrm{T}_{3}$ & 10.45 & 0.976 & 2.062 & 0.945 & -8.966 & 0.975 & 0.673 & 1.233 & 0.991 \\
\hline $\mathrm{T}_{4}$ & 7.434 & 0.990 & 2.118 & 0.914 & -12.25 & 0.962 & 0.743 & 1.171 & 0.996 \\
\hline $\mathrm{T}_{5}$ & 24.34 & 0.768 & 1.897 & 0.689 & 2.624 & 0.903 & 0.498 & 1.442 & 0.914 \\
\hline $\mathrm{T}_{6}$ & 17.19 & 0.904 & 1.990 & 0.885 & -3.333 & 0.971 & 0.579 & 1.346 & 0.981 \\
\hline $\mathrm{T}_{7}$ & 14.53 & 0.936 & 2.018 & 0.985 & -6.239 & 0.983 & 0.655 & 1.278 & 0.990 \\
\hline $\mathrm{T}_{8}$ & 13.06 & 0.948 & 2.032 & 0.991 & -7.587 & 0.984 & 0.690 & 1.241 & 0.991 \\
\hline $\mathrm{T}_{9}$ & 23.20 & 0.783 & 1.909 & 0.704 & 1.336 & 0.909 & 0.526 & 1.418 & 0.925 \\
\hline $\mathrm{T}_{10}$ & 16.73 & 0.906 & 1.992 & 0.885 & -3.771 & 0.970 & 0.591 & 1.334 & 0.982 \\
\hline $\mathrm{T}_{11}$ & 12.50 & 0.957 & 2.036 & 0.974 & -7.640 & 0.982 & 0.667 & 1.253 & 0.993 \\
\hline $\mathrm{T}_{12}$ & 11.94 & 0.959 & 2.061 & 0.982 & -8.986 & 0.981 & 0.712 & 1.226 & 0.995 \\
\hline
\end{tabular}

Table 7: Release Kinetics Studies of the Prepared Formulations

\section{Conclusion}

In the present work, bioadhesive controlled release microspheresof Zaltoprofen using Sodium alginate along with HPMC K100M, HPMC K15M, XANTHAN GUMas copolymers were formulated to deliver Zaltoprofen via oral route.

Details regarding the preparation and evaluation of the formulations have been discussed in the previous chapter. From the study following conclusions could be drawn:-

- The results of this investigation indicate that ionic cross linking technique Ionotropic gelation method can be successfully employed to fabricate Zaltoprofen microspheres. The technique provides characteristic advantage over conventional microsphere method, which involves an "all-aqueous" system, avoids residual solvents in microspheres. Other methods utilize larger volume of organic solvents, which are costly and hazardous because of the possible explosion, air pollution, toxicity and difficult to remove traces of organic solvent completely.

- $\quad$ FT-IR spectra of the physical mixture revealed that the drug is compatible with the polymers and copolymers used.

- Micromeritic studies revealed that the mean particle size of the prepared microspheres was in the size range of 512-903 $\mu \mathrm{m}$ and are suitable for bioadhesive controlled release microspheresfor oral administration.

- Increase in the polymer concentration led to increase in \% Yield, $\%$ Drug entrapment efficiency, Particle size, \% swelling and \% Mucoadhesion.

- The in-vitro mucoadhesive study demonstrated that microspheres of Zaltoprofen using sodium alginate along with HPMC K100M as copolymer adhered to the mucus to a greater extent than the microspheres of Zaltoprofen using sodium alginate along with HPMC K15M and XANTHAN GUM as copolymers.

\section{References}

1. Mulugeta Fentie, (2015). Anteneh Belete and Tsige GebreMariam Formulation of Sustained Release Floating Microspheres of Furosemide from Ethylcellulose and Hydroxypropyl Methylcellulose Polymer Blends J Nanomed Nanotechnol 6:1

2. Abhijeet A. Durgavale, Archana R. Dhole, Shrinivas K. Mohite, Chandrakant S, (2012) . Magdum Formulation and Evaluation of Floating Microsphere of Captopril using Different Gas Forming Agents. Am. J. PharmTech Res. 2(2)
3. A Salomy Monica Diyya, V Rakesh Kumar,( 2015). Formulation and In Vitro Evaluation of Floating Microspheres of Glipizide, Volume 3 (2), Page-606-615 606 IIIIIIIII@ International Journal of Pharma Research and Health Sciences. All rights reserved CODEN (USA)-IJPRUR, e-ISSN: 2348-6465.

4. Megha Sharma, Seema Kohli, Agnimitra Dinda In-vitro and invivo evaluation of repaglinide loaded floating microspheres prepared from different viscosity grades of HPMC polymer.

5. Saudi Pharmaceutical Journal Available online 27 February 2015

6. Pavan Kumar Perumandla, Sree Priya. Formulation And In Vitro Evaluation Of Floating Microspheres Of Dextromethorphan Hydrobromide , International Journal of Pharmacy and Pharmaceutical Sciences ISSN- 0975-1491 Vol 6, Issue 4, 2014.

7. S.K.Senthilkumar, B.Jaykar, S.Kavimani, (2010). Formulation, Characterization and Invitro Evaluation of Floating Microsphere Containing Rabeprazole Sodium, /JITPS Vol.1 (6), 274-282.

8. V. Sai Kishore, B. Tejeswara Rao, K. Pavani, D. Nagasen, K. Rakesh Varma and D. Gowtham Plantago Ovata Seeds And Bhringaraj, (2013). Leaves As Superdisintegrants: Formulation And Evaluation Of Sotalol Hydrochloride Orodispersible Tablets IJPCBS 3(4), 1040-1046

9. Sanjeev Kumar, Tara Chand,(2013).Formulation and Development of Floating and Mucoadhesive Microspheres of Clarithromycin ,The Pharma Innovation - Journal Vol. 2 No. 5

10. Mukesh P. Ratnaparkhi, Suresh B. Dhiwar, Kiran E. Dhage, Sharvari S. Bhore, Pratiksha M. Kadam and Pradeep S. Patil (2012) Formulation and in-vitro characterization of floating microspheres of Metfomin $\mathrm{HCl}$,Scholars Research Library Der Pharmacia Lettre, 4 (5):1390-1400.

11. Kapil Kumar and AK Ra, (2012). Development and Evaluation of Floating Microspheres of Curcumin, Tropical Journal of Pharmaceutical Research October 11 (5): 713-719

12. Parmar Kunal Vinodbhai a, Dr. M.C. Gohel b, Dr. R.K. Parikh b, Dr. Shital Bariyac Ms. Rajeshvari N. Suthar Sustained Release Floating Microspheres Of Acyclovir: Formulation, Optimization, Characterization And In Vitro Evaluation International Journal of Drug Development \& Research | JanMarch 2011 | Vol. 3 | Issue 1 | ISSN 0975-9344 | Available online

13. Kumar Darapu B.N*, K. Sundaramoorthy And T.Vetrichelvan ,(2010) Formulation And In-Vitro Evaluation Of Gastroretensive Floating Microspheres Of Ranitidine Hydrochloride Vol.1 (2) Nov-Dec-An International Journal of Advances In Pharmaceutical Sciences

14. Singh Bandana, Kanoujia Jovita, Pandey Manisha*, Saraf Shubhini A.( 2010) Formulation and Evaluation of Floating Microspheres of Famotidine, International Journal of 
PharmTech Research CODEN (USA): IJPRIF ISSN : 09744304 Vol.2, No.2, pp 1415-1420, April-June .

15. M.K. Deepaa, M. Karthikeyanb,(2009) Cefpodoxime Proxetil Floating Microspheres: Formulation and In Vitro Evaluation, Iranian Journal of Pharmaceutical Sciences Spring 5(2): 69-72.

16. Yuveraj Singh Tanwar, Pushpendra Singh Naruka, Garima Rani Ojha, (2007). Development and evaluation of floating microspheres of verapamil hydrochloride, Revista Brasileira de Ciências Farmacêuticas Brazilian Journal of Pharmaceutical Sciences vol. 43, n. 4, out./dez.

17. Rahaman Z, Ali M, Khar RK,(2006). Design and evaluation of bilayer floating tablets of captopril, Acta Pharma. 56(1): 49-57.

18. Tanwar YS, Naruka PS, Ojha GR,(2007).Development and evaluation of floating microspheres of verapamil hydrochloride, Brazilian J Pharm Sci. Vol:43(4): pg- 529-534.

19. Lee TW, Robinson JR, (2001).Remington: The Science and Practice of Pharmacy.20th Ed. Pennsylvania. Mack Publishing Company.

20. Naisarg D. Pujara, Namrata V. Patel Ankita P. Thacker, B rahmdutta K. Raval. Sumit M. Doshi, Ramesh B. Parmar, (2012). Floating Microspheres: A Noval Approach for Gastro Retention. World Journal Of Pharmacy and Pharmaceutical Sciences, Vol:1(3), pg-872-895.

21. Shwetha Kamath K, Senthil Kumar S.K,(2012).Design and evaluation of floating microspheres of Rabeprazole Sodium, International Journal of Pharmacy and Pharmaceutical sciences, Vol: 4(3); Pg-357-367.

22. Anand Gadad, Chirag Naval, Krunal Patel, Panchaxari Dandagi and Vinaya.(2011). Formulation and evaluation of floating microspheres of captopril for prolonged gastric residence time, Indian Journal of Novel Drug Delivery, Vol:3(1), pg- 17-23.

23. Amol V. Pande, Pravin D. Vaidya, Aseem Arora, Madhura V. Dhoka,(2010) In-vitro and In-vivo evaluation of ethyl cellulose floating microspheres of cefpodoxime proxetil, International Journal of Pharmaceutical and Biomedical Research, Vol:1(4), pg-122-128.

24. Patil Hemangi S, Patil Moreshwar P, Tekade Bharat W, Thakare Vinod M,and Vijay R , ( 2009) Formulation and In-Vitro Evaluation of Floating Microspheres of Acyclovir, Arch Pharm Sci \& Res, 1(1), 194 -198.

25. Deepaa M.K. and Karthikeyanb M, (2009).Cefpodoxime Proxetil Floating Microspheres: Formulation and In Vitro Evaluation, Iranian Journal of Pharmaceutical Sciences, 5(2), 6972.

26. Srivastava Anand Kumar, Ridhurkar Devendra Narayanrao, Wadhwa Saurabh,(2005). Floating microspheres of cimetidine: Formulation, characterization and in vitro evaluation, Acta Pharm, 55, 277-285.

27. Sanjay S. Patel, S.Ray and R.S. Thakur, Formualtion and Evaluation of Floating Drug Delivery System containing Clarithromycin for Helicobacter Pylori, Acta Poloniae Pharmaceutica - Drug Research, 63(1), 53-61.

28. Patel Asha, Ray Subhabrata and Thakur Ram Sharnagat,(2006).In Vitro Evaluation and Optimization of Controlled Release Floating Drug Delivery System of Metformin Hydrochloride, DARU, 14( 2), 57-64.

29. Chien YW. (1992) Novel drug delivery system, Marcel Dekker Inc Publications: New York, 2(50): 16172.

30. Khar RK, Vyas SP, (2002). Targeted and controlled drug delivery novel carrier system, CBS Publishers and Distributors: New Delhi, 1: 417-54.

31. Arora S, Ali J, Ahuja A, Khar RK, Baboota S,( 2005). Floatng drug delivery systems: A review, AAPS Pharm Sci Tech 6(3): 372-390.
32. Wahlstrom B, Blennow G, (1978). A study on the fate of curcumin in the rat, Acta Pharmacol Toxicol, 43: 86-92.

33. Anand P, Kunnumakkara AB, Newman RA.( 2007). Bioavailability of Curcumin: Problems and Promises, Mol Pharmaceutics, 4 (6): 807-818.

34. Srivastava A, (2005). Floating microspheres of cimetidine: formulation, characterization and in vitro evaluation, Acta Pharm, 55: 277-285.

35. Maheswari U, Jain S, Bhadra D, Jain NK,(2003).Floating microspheres bearing acetohydroxamic acid for the treatment of H. pylori, J Pharm Pharmacol, 55: 1607-1613.

36. Higuchi WI. (1962).Analysis of data on the medicament release from ointments, J Pharm Sci, 51:802-804.

37. Korsmeyer RW, Gurny R, Doelker EM, Buri P, Peppas NA,(1983).Mechanism of solute release from porous hydrophilic polymers, Int J Pharm, 15: 25-35.

38. Rahman MH, Telny T, Kumaraswamy K. (2010).Comparative evaluation of HPMC K100 and poloxamer 188 - influence on release kinetics of Curcumin in floating microspheres, $R J$ Pharm Chem Biol Sci, 1(2): 28-34.

39. G.K. Jani, M. C, Gohel, (1997).Journal of Controlled Release, $43,245250$.

40. Shashikant D. Barhate1, et al, Formulation and Evaluation of Floating Microspheres of Ketorolac Trometamol, IJPRD/2009/Pub/Arti/Vov-1/Issue-9/Nov/005.

41. Yogesh S Gattani, Durgacharan A Bhagwat, Akhil P Maske, (2008).Asian Journal of Pharmaceutics. October December.

42. Asha patel, subhabrata rayra, et al., DARU, 2006, 14(2).

43. M. Saravanan, K. Bhaskar, G. Srinivasa Rao and M.D. Dhanaraju. J. Microencapsulation 2003, 20 (3), 289 - 02.

44. Iannuccelli V, Coppi G, et al., Int J Pharm, 1998, 174; 47 - 54.

45. Lee J H, Park T G, Choi H K. J Microencapsules, 1999, 16(6), $715-729$.

46. Streubel A, Siepamann I, Bodmeier R, Int J Pharm, 2002, 241, $279-82$.

47. Ravi Kumar, Swati Patil, (2009).International Journal of Chem Tech Research, Oct-Dec Vol.1, No.4, pp 815- 825.

48. Arora S, Ali J, Ahuja A, Khar R.K., Baboota S, (2005). Floating Drug Delivery Systems: A Review. AAPS PharmSciTech, 06(03): E372-E390.

49. Talukder, R., Fassihi R, (2004). Gastroretentive drug delivery system: A mini review. Drug Dev. Ind. Pharm., Vol.30, pp.10191028.

50. Mr. Tanwar Y.S, (2006).Floating microspheres: Develpoment, Characterization and applications, Pharmainfo.net, Vol. 4, Issue 3.

51. Gaba Punam, Floating microspheres: A Review, Pharm info. net ,2008, Vol. 6 , issue 5 .

52. Merck manual online drug library and www. merck.com

53. Uchida T, Yoshida K, Goto S, (1996). Preparation and characterization of poly-lactic acid microspheres containing water soluble dyes using a novel w/o/w emulsion solvent evaporation method. J Microencapsulation. 13;219-228.

54. Meral Yuce, Kandemir canefe, (2008).Indomethacinloaded microspheres: preparation, characterization and in-vitro evaluation regarding ethyl cellulose matrix material, Turk $J$. Pharm. Sci, 5 (3) 129-142.

55. Aphale s, shinde s, (2011) Development and evaluation of hollow microspheres of clarithromycin as a gastroretentive drug delivery system using eudragit polymers, Int. J. of Pharma and Bio Scie., 2, 344-358.

56. Tejaswi BS, Formulation and in vitro evaluation of clarithromycin floating microspheres for eradication of helicobacter pylori, Der Pharmacia Lettre, 3, 2011,90-101. 
57. Pant P, Bansal K, and Rao RT, (2011). Formulation design and evaluation of gastroretentive mucoadhesive microspheres of clarithromycin, IJRPC 1, 347-351.

58. Sarojini AS, Kumar AP, and D Pradeep,(2010).Formulation and evaluation of albumin- chitosan floating microsphere containing clarithromycin and estimation by spectrophotometric method, RJPBCS, 1, 207-214.

59. Srivastava, A. K.; Ridhurkar, D. N., Wadhwa, S, (2005). Floating microspheres of cimetidine: formulation, characterization and in vitro evaluation. Acta Pharm., v.55, p.277-285.

60. Thummel, K. E.; Shen, D. D, (2020).Design and optimization of dosage regimens: pharmacokinetic data. In: Hardman, J. G.; Limbirel, L. E.; Gilman, A. G., eds. Goodman and Gilman's The pharmacological basis of therapeutics. New York: Mc. Graw Hill, 2001.

61. V. S. Mastiholimath, P. M. Dandagi, a. P. Gadad, Rashmi mathews, \& a. R. Kulkarni,(2008) In vitro and in vivo evaluation of ranitidine hydrochloride ethyl cellulose floating micro particles, Journal of Microencapsulation. 25(5): 307-314.

62. Wakode RR, Bajaj AN (2008), Formulation and characterization of pramipexole loaded microspheres.

63. BC Behera, SK Sahooa, S Dhala, BB Barika, BK Guptab ,(2008).Characterization Of GlipizideLoaded Polymethacrylate Microspheres Prepared By An Emulsion Solvent Evaporation Method, Tropical Journal of Pharmaceutical Research, 2008; 7 (1): 879-885.

64. Yasunori Sato, Yoshiaki Kawashima, Hirofumi Takeuchi,(2003).Physicochemical propertie to determine the buoyancy of hollow microspheres (microballonss) prepared by the emulsion solvent diffusion method. European journal of pharmaceuticsand biopharmaceutics; (55), 297-304.

65. Soppimath KS, Kulkarni AR, Rudzinski WE, Aminabhavi TM,(2002). Microspheres as floating drug-delivery systems to increase gastric retention of drugs, Drug Metab Rev 33:149-60.

66. Muthusamy K, Govindarazan G, Ravi TK, (2005). Preparation and evaluation of lansoprazole floating micropellets Indian Journal of Pharmaceutical Sciences 67:75-9.

67. Thanoo C, Sunny MC,Jayakrishnan A. (1993).Oral sustainedrelease drug delivery systems using polycarbonate microspheres capable of floating on the gastric fluid, $J$ Pharm Pharmacol;45:21-4.

68. Joseph NJ, Lakshmi S, Jayakrishnan A, (2002). A floating-type oral dosage form for piroxicam based on hollow polycarbonate microspheres: In vitro and in vivo evaluation in rabbits. J Control Release; 79:71-9.

69. Stithit S, Chen W, Price JC, (1998). Development and characterization of buoyant theophylline microspheres with near zero order release kinetics, J Microencapsul 15:725-37.

70. Lee JH, Park TG, Choi HK, (1999). Development of oral drug delivery system using floating microspheres, J Microencapsul 16:715-29.

71. Gladiziwa U, Klotz U,(1993).Pharmacokinetics and pharmacodynamics of $\mathrm{H} 2$ receptor antagonists in patients with renal insufficiency, Clin Pharmacokinet 24:319-32.

72. Martin A and Swarbrick J,(1993).Physical pharmacy, 3rd edition, Mumbai: Varghese publishing house,444- 447.

73. Indian pharmacopoeia. Monographs on dosage forms. The Indian pharmacopoeia commission, Ghaziabad. [2007];3:182183.

74. Indian pharmacopoeia. Monographs on dosage forms. The Indian pharmacopoeia commission, Ghaziabad. 2007;3:177-178.
75. Indian pharmacopoeia. Monographs on dosage forms. The Indian pharmacopoeia commission, Ghaziabad. 2007;3:183-184.

76. USP 27/NF 22, Asian edition, General test procedures, U.S. Pharmacopoeial convention, Rockville MD. 2000;1677- 1678.

77. Battue SK, Repay MA, Maunder S and Rio M Y.( 2007) Formulation and evaluation of rapidly disintegrating tablet Fenoverine tablets: Effect of superdisintegrants, Drug Dev Ind Pharm. 33:1225- 1232.

78. Sunada H, Yonezawa Y, Danjo K,Otsuka A and Iida K.( 1996). Preparation and evaluation of a compressed tablet rapidly disintegrating in the oral cavity, Chem Pharm Bull (Tokyo). 44: 2121-2127.

79. Basu S, Adhiyaman R (2008). Preparation and characterization of nitrendipine loaded eudragit RL100 microspheres prepared by an emulsion-solvent evaporation method, Trop J Pharmaceut Res 7: 1033-1041.

80. Yang Y, Chung T, Bai X, Chan W (2000). Effect of preparation conditions on morphology and release profiles of biodegradable polymeric microspheres containing protein fabricated by double emulsion method. Chem Eng Sci 55: 2223-2236.

81. Atyabi F, Mohammadi A, Dinarvand R, (2005).Preparation of nimodipine loaded microspheres: Evaluation of parameters, Iran J Pharm Sci 1: 143-152.

82. Basu S, Kavitha K, Rupeshkumar M (2010).Evaluation of ketorolac tromethamine microspheres by chitosan/gelatin complex coacervation, J Pharm Pharm Sci 78: 79-92.

83. Freiberg S, Zhu X (2004). Polymer microspheres for controlled drug release, Int J Pharm 282: 1-18.

84. Nighute A, Bhise S, (2009).Preparation and evaluation of rifabutin laded polymeric microspheres, Res J Pharm Tech 2: 371-374

85. Guyot M, Fawaz F, (1998).Nifedipine loaded-polymeric microspheres: preparation and physical characteristics, Int J Pharm 197: 61-74.

86. Das M, Maurya D, (2008).Evaluation of diltiazem hydrochloride-loaded mucoadhesive microspheres prepared by emulsification internal gelation technique. Acta Pol Pharm-Drug Res 65: 249-259.

87. Nath B, Nath L, Mazumder B, Kumar P, (2010). Preparation and characterization of salbutamol sulphate loaded ethyl cellulose microspheres using water-in-oiloil emulsion technique, Iran $J$ Pharm Res 9: 97-105.

88. Anand kumar, srivastava devendra, narayanrao ridhurkarsaurabh wadhwa, (2005). Floating microspheres of cimetidine; Formulation, characterization and in vitro evaluation: Acta Pharm 55: 277-285.

89. Arai, K. Kineemaki T, Fujita T, Bull Tokai, Reg. Fish.Res.Lab; 1968: 56-89.

90. Arjun Sony, Sonam Jain, (2013). Formulation \& evaluation of floating microspheres of flupirtine Maleate; international journal of pharmacy \& life sciences: Int. J. Of Pharm. \& Life Sci 4(4): 2535-2540

91. Arul B, Kothai R., Sangameswaran B, Jayakar B, (2003). Formulation and Evaluation of Microspheres Containing Isoniazid; Indian Journal of Pharmaceutical Sciences: 65 (6): 640-642.

92. Hazner Dar S, (2004). Preparation and in vitro evaluation of Eudragit microspheres containing acetazolamide; International journal of pharmaceutics: 269: 131-140. 